\title{
Integrating gender and religion: Social transformation for strengthening identity among Indonesian Muslim Migrant Workers
}

\author{
Anggaunitakiranantika* \& P.P. Anzari \\ Universitas Negeri Malang, Malang, Indonesia
}

\begin{abstract}
In Indonesia, as the highest Muslim population country worldwide, patriarchy systems are correlated with Islamic norms and values used for controlling human behavior, including the relationships of men and women. Addressing this issues, Muslim women try to expand their capabilities by migrating to Hong Kong as migrant workers. This research aims to study Indonesian Muslim women in Hong Kong based on their gender identity and religious value. A qualitative method was used. Applying purposive samples, research focused on Indonesian migrant workers in Hong Kong who joined a Muslim community. Research found that women's transformation is strengthened by gender and religion, which used for reinforcing as Muslim Indonesian migrant worker activities and Muslim women community practices among Javanese Muslim women at Hong Kong.

Research found that migration roles as a part of Muslim women new value, which is give a flexibility for Muslim women for working abroad as the transformation. In addition, Muslim women transformation in Hong Kong not only interpreted as individual norms but also manifested in collective activities during their leisure time in Hong Kong for strengthening Muslims women identity.
\end{abstract}

Keywords: gender, religion, social transformation, Indonesian migrant worker

\section{INTRODUCTION}

International migration by Indonesian women is increasingly prevalent and is carried out to diverse Asian countries. Increased demands and living costs trigger the increase of Indonesian women entering the public sector by becoming Indonesian Migrant Workers (IMW). Ionesco and Agzaharn (2009) stated that male and female relations are affected by living expense changes in society. As a result, people are forced to migrate according to gendered and geographical factors, which are governed by sets of laws and regulations from each country. Furthermore, migration often implies economic and social costs and benefits for both males and females, who participate in international migration.

East Java is the one of the provinces in Indonesia that contributes the highest number of migrant workers in several Asian countries. East Java provides Muslim laborers that migrate to many Asian countries such as Hong Kong, Singapore, Malaysia, Taiwan, and South Korea. A small part of the data on Indonesian labor shows increasing interest in earning from other countries, despite the risks to migrant workers. One of the attractive reasons for short term international migration is the success of fellow migrants measured by the possession of financial remuneration or remittance that they send to their home regions (Constable, 2010; Anggaunitakiranantika, 2016; Hamidi, 2017; Allmark \& Wahyudi, 2019).

Intersectionality factors against Javanese women who work as migrant workers in Hong Kong explain the diverse socially and culturally constructed categories which interact at different levels

\footnotetext{
*Corresponding author: anggaunita.fis@um.ac.id
} 
to produce different forms of relations and inequalities (Kiranantika, 2020). The social and cultural constructions which are recognized as patriarchy systems tend to put women in an unequal position like patron-client, labor worker-employer, labor worker-recruiting agency, employer-recruiting agency, and local worker-migrant worker (from different regions). The inequality commonly faced by Indonesia's female migrant workers are exploitation, remuneration which is below the standard of ILO's labor regulations, abuse (physical, verbal, and psychological) against migrant workers, negative stereotypes and stigma regarding Muslim migrant workers, and Islamophobia triggered by any Muslim-related activities conducted by migrant workers in Hong Kong.

Meanwhile, the preliminary studies showed that Muslim women and Indonesian migrant workers are still bound to their responsibilities of doing worship appropriately, despite being away from their country and living in different surroundings in Hong Kong. Interestingly, by being religious minorities in Hong Kong, they are involved in preaching and Islamic Hadith interpretation as a weekly agenda for strengthening their identity among Hong Kong peoples. By elaborating on gender perspectives for pointing out that women have their own life meanings and other capabilities instead of just being workers, the Muslim communities of Indonesian women workers in Hong Kong tend to build their identity through positive attitudes. Commonly, researchers limit their scope of observations on international migrant workers on remittance and migration experience by socioeconomic conditions. This paper will be analyzing how Indonesian Muslim women who work as migrant workers perceive the gendered notion regarding their migration to Hong Kong and identifying the effects of Muslim spiritual activities in Hong Kong as new residents which different from the Chinese traditions there.

\section{METHODS}

This study employed a qualitative method with a phenomenology as the design for data gathering. It was used to captured written and oral descriptive data from people and observable behavior in Hong Kong. This method was chosen because the present study examines holistic, complex, dynamic, and meaningful problems. In addition, the qualitative method is part of the knowledge that can be considered a social product and a social process (Neuman, 2000). The data was collected from female Indonesian Muslim migrant workers working in Hong Kong. Several steps were used in collecting the data, namely: reading critically, making notes, conducting participant observation, analyzing the data, and concluding the substance of the study (Miles \& Huberman, 1994). Additionally, participant-observation amid Indonesian migrant worker organizations in Hong Kong was used for gathering information and collecting the additional data.

In addition, Sheller (2011) suggested that research in mobility allows to see what defines social science along with the material and political relations that construct the structure of the world. Therefore, the purpose of this study is to reflect the relationship between the observed and the observer. This study also seeks to uncover natural settings on weekly religious activities through social phenomena enacted by Indonesian Muslim women as Indonesian migrant workers in Hong Kong. Participants were recruited using a purposive sampling technique. The Javanese Muslim communities in Hong Kong are the biggest association for Muslim migrant workers from Indonesia. Further in-depth interview and observation were conducted to eleven Javanese Muslim women from Muslim communities in Hong Kong. They were all domestic workers and caregivers in Hong Kong and have worked for at least four years. This study was conducted from February to November 2019.

The research location was a Hong Kong district with many migrant workers (a melting pot), namely Causeway Bay district, that has been part of the public sphere in Hong Kong since early 2000. Causeway Bay has always been a chosen place for gathering, especially for women migrant workers from Indonesia. To obtain more information, two Muslim community leaders and an Indonesian migrant-employer in Hong Kong are chosen as research subjects for the phenomenon related to gender notions and religion activities, which are embedded in Indonesia migrant workers. 


\section{RESULTS AND DISCUSSION}

\subsection{Gender belief systems among Indonesian Muslim women in Hong Kong}

Being migrant workers in Hong Kong is an initial step action for Indonesian Muslim women to reject discrimination and subordination which come from masculine superiority in Javanese societies or the so-called patriarchal system. Indonesian people are engaged in a patriarchal system which puts men as superior to women. It has been constructed for a long time and rigidly bound together men and women throughout time. Nowadays, this system has been changed by mobility. While mobility is considered a common thing for Indonesian men only, Indonesian women are considering to be living beyond the norms. Indonesian people, especially Javanese women, used to be allowed to nurture their family and work in domestic sectors only as migration might disrupt predominant Javanese cultural values.

Both Koning et al (2000) and Mahler and Pessar (2001) claimed that the discourse of womanhood in Indonesia, in this case named ibuism, and the discourse of traditional cultural values are ingrained in kin-based institutions in Indonesia, especially for Javanese people. As a result, also mentioned by William and Widodo (2009), the so-called 'feminine jobs' restrict the choices of occupation available for women. These conditions are still existing to this day. As in Javanese culture, women are still restricted from certain occupations despite their increased access to education as well as vocational and professional training, the two major forces in women lives. Javanese people believe that women must live more in the domestic life rather in the public.

Reflecting to this case, the process of Indonesian Muslim women embarking towards independence roots from living in a patriarchal system, wherein a father or husband uses political hegemony in treating women in the name of respecting the culture. Women are only permitted to perform activities in a restrictive sector, namely the domestic sector. This condition has aggravated the lower bargain position for women in Indonesia as this system sets women up to be taken for granted in family decision making. All decisions must be decided by a man. Furthermore, this custom is supported by the local bureaucrats in Indonesia who gain opportunities from this situation. To illustrate this case, when a woman wishes to work abroad, she must acquire the permissions from their spouse or father or uncle or brother. If this requirement is not included on the form to be submitted to the government, it will result in her paying more than women who include permissions from their male relatives. In other words, the requirements for engaging Indonesian women in work are very rigid and requires various recommendations from the spouse or father.

Based on the observation, women workers in this study are generally married and leave their children with their husbands and are supported also by their extended family. Javanese women usually sign four-to-eight-year contracts with their recruitment agency, a consideration amount due to family needs and basic needs. In addition, Javanese women who decided to be Indonesian migrant workers in Hong Kong also said that they really want to prove that they are capable of changing their future and, therefore, contradicting the patriarchal believes which are embedded into Javanese society, such as the idea that being a female migrant worker is associated with having low skills, being a needy and low educated person, and that they should stay at home for their family. By working abroad as migrant workers, Javanese women have clear goals in their mind for showing their capabilities, the ability to live independently by being away from their families and having working competence instead of adhering to the labels and stigmas from others in Indonesia given to them.

The result of this study is connected with a new direction in the theory of mobility and is also a response to several important feminist critiques of mobility theory that point out it is grounded in masculine subjectivity, makes assumptions about freedom of movement, and ignores the gendered production of space. Skeggs (2004) argued that the (old) mobility paradigm could be linked to a 'bourgeois masculine subjectivity' that describes itself as 'cosmopolitan' and pointed out that 'mobility and fixity are figured differently depending on national spaces and historical periods' (Skeggs, B. 2004). This is appropriate to the migration experience of Javanese women, particularly those who considered their mobility as an initiative of the patriarchal system as settled social 
structures. International migration performed by Javanese women acts as a form of liberation for women and a response to patriarchal culture which clings onto the subjectivity principle of supporting male dominance in social structure.

Ridgeway and Correll (2004) stated that one of the core elements which makes up the gender system is cultural beliefs and their impact, namely "social relational" impact. In Addition, when gender has a salient role in different contexts, cultural beliefs regarding gender systematically create bias on the behaviors, performance, and evaluations of men and women. In this research, Javanese women who work as migrant workers in Hong Kong showed rationality toward their migration decisions. They were only given the domestic sector to explore in Indonesia and once they migrated to Hong Kong, they got pay and the freedom to live independently. By migrating internationally, these Javanese women left their house to go to a faraway country for a long period of time and thus obtained salvation from being liberated from the culture that caused "scars", because the gender identity of Javanese women in Hong Kong was constructed by independence, knowledge, and insights from being migrant workers. Such rationality possessed by Javanese women makes the difference in the mobility dynamic context becoming more developed. By being Indonesian migrant workers in Hong Kong, Javanese women can obtain working experience and have broad knowledge in being true women in another country.

\subsection{Perpetuating minorities: Indonesian Muslim women's'journey in Hong Kong}

The period of social change is described by social anthropologists as a period of "liminality" in communities in which bonds are egalitarian and all possibilities are open. Turner (1974) argued that community is considered sacred or "holy" almost everywhere, possibly because it goes beyond the norms that rule structured and institutionalized relationships and is accompanied by experiences of unprecedented potency. Furthermore, Runnals (2002) stated that it is essential to study women's positions in religions regarding social systems which are significantly imbued with gender concepts that are related to divinity, considering that gender configurations are both behavioral and symbolic. The hegemonic system which delivered Javanese people in patriarchal system are also described in many ways and in many concepts.

On the other hand, Appadurai (2006) noted that "predatory identities," which stem from the small gap between majority status and total national ethnic purity, can be the source of extreme ire against certain ethnic others. The grounds for such incidents are the inner interactions between the majority and minority. Then, he further stated that, incensed by the fear of being driven to become minorities, and the fear that the minorities can readily take their place, majorities can be mobilized to react to perceived dangers (Appadurai, 2006). In line with this study, the holy activities of Indonesian Muslim women are seen when they have opportunities and freedom to express their activities. Notably, Hong Kong's culture and regulation allowed them to pay attention to some restrictions, but Indonesian Muslim women see this not as a barrier, but as a challenge of Muslim ritual activities abroad (Table 1).

For Muslim women in Hong Kong, specifically those who work as an Indonesian migrant worker, assembling together on the weekend was a form of a refreshment activity, strengthening their sense of nationalism as they live a Hong Kong multicultural life and is also a form of gratitude to God for the chance to live another day as a better person. Reflecting on the concept of reciprocity by Rapoport et al., (2002), it is unlikely that these female migrant workers can spend much time away from their work. Javanese migrant workers often work an unclear number of hours and do not have fixed job descriptions due to their being domestic workers in Hong Kong. Nevertheless, they still allocate time for conducting religious activities together with other Muslim women from Indonesia, despite the possibilities of them being called to come back to serving their employers. These religious activities are binding for migrant workers in whole Hong Kong districts. Not only for Javanese Muslim migrant workers around Causeway Bay district and Mong Kok district, but also in the Kowloon mosque which is the largest mosque in Hong Kong, and other mosques in other Hong Kong districts. Having such activities is meant for Muslim women as ways to feel the security of being minorities. 
Table 1. Muslim Women Religious Activities in Hong Kong Table.

\begin{tabular}{|c|c|c|c|}
\hline & Types of Activities & Time (Flexibility) & Place \\
\hline Activity 1 & Doing Recitation/Preaching & Weekly & $\begin{array}{l}\text { Mosque, Hong Kong Dis- } \\
\text { trict public sphere area }\end{array}$ \\
\hline Activity 2 & $\begin{array}{l}\text { Tausiyah/Islamic Hadith review- } \\
\text { ing }\end{array}$ & Weekly/ Twice a month & $\begin{array}{l}\text { Mosque, Hong Kong Dis- } \\
\text { trict public sphere area }\end{array}$ \\
\hline Activity 3 & $\begin{array}{l}\text { Ziarah (pilgrimage) Tour to } \\
\text { Islam community in Mainland } \\
\text { China (Uyghur) }\end{array}$ & Quarter in a year & $\begin{array}{l}\text { Certain place in Hong } \\
\text { Kong District (Bus Sta- } \\
\text { tion) }\end{array}$ \\
\hline Activity 4 & $\begin{array}{l}\text { Singing Islamic songs, Qasidah } \\
\text { and Hadrah (Singing Islamic } \\
\text { songs accompanied by Rabanna } \\
\text { and polite-slow motion) }\end{array}$ & Weekly/Twice a month & $\begin{array}{l}\text { Hong Kong District public } \\
\text { sphere area }\end{array}$ \\
\hline Activity 5 & $\begin{array}{l}\text { Fund raising for Shodaqoh and } \\
\text { Infaq }\end{array}$ & Weekly & $\begin{array}{l}\text { Mosque, Hong Kong Dis- } \\
\text { trict public sphere area }\end{array}$ \\
\hline Activity 6 & $\begin{array}{l}\text { Buka Bersama, Shalah Taraweeh } \\
\text { (Fast-breaking together during } \\
\text { Ramadhan followed by shalah } \\
\text { sunnah) }\end{array}$ & Twice in Ramadhan Month & $\begin{array}{l}\text { Certain place in Hong } \\
\text { Kong District }\end{array}$ \\
\hline Activity 7 & Eid Celebration & $\begin{array}{l}\text { Twice a year (Eid Fitri and } \\
\text { Eid Adha) }\end{array}$ & $\begin{array}{l}\text { Mosque, Hong Kong Dis- } \\
\text { trict public sphere area }\end{array}$ \\
\hline
\end{tabular}

In line with these research findings, Bertrand (2004); Hamidi (2017) and Anggaunitakiranantika $\&$ Hamidi (2020) explained that conflict might be triggered by certain economic drivers, but this can be exacerbated more when combined with differences in religious and ethnic identities. Conflicts have been faced by Javanese Muslim women with their families in Indonesia, but migration has offered better opportunities in working and public participation, including delivering the ideas to others and achieving women's goals. Research found that religious activities were mostly held during their leisure time in Hong Kong. It has been running this way for many years without any race differentiation and is open for any migrant worker in Hong Kong. Based on the activities among Javanese Muslim women in Hong Kong, only Muslim women from Indonesia could attending all types of religious activities in Hong Kong and they were only recognized as Indonesian Muslim women with their religious customs. In Hong Kong, Islamic identities are not only represented by their appearance, such as wearing hijab and long apparel, but also by their behaviors, such as eating and drinking halal foods and beverages. Integration sheds light into constructed categories which interact with, among others, gender beliefs and religion levels to produce different forms of power relations. Javanese Muslim integrity shows through such religious activities as the Indonesian Muslim migrant workers have the power to voice inequalities which arise due to conflicts and gaps among the patriarchal system in Indonesia and the participation of women in Hong Kong as migrant workers. Furthermore, the migration decision among Indonesian women somehow could reduce the hegemonic perception for positioning women's identities, especially by integration into the workforce.

\section{CONCLUSION}

The integrating of gender and religion in the case of Indonesia migrant workers nowadays is a part of women's social transformation and is proof of positive Muslim activities abroad. Javanese Muslim women who work in Hong Kong are still practicing their religious beliefs by conducting activities for strengthening their identity. Thus, the identity of Indonesians as one of largest communities in the world is also sustained through the female migrant workers in Hong Kong. They are not 
just hindered by gendered ideas of patriarchal systems which twisted their flexibility as Indonesian women but become embedded in a strong and vibrant community of Muslim representation abroad by being Indonesian migrant workers in Hong Kong.

\section{REFERENCES}

Allmark, P., \& Wahyudi, I. 2019. Travel, sexuality, and female Indonesian domestic migrant workers in Hong Kong. Continuum, 33(5), 630-642.

Anggaunitakiranantika, A. 2016. Awakening Through Career Woman: Social Capital for Javanese Migrant Worker in Southeast Asia. In ASEAN/Asian Academic Society International Conference Proceeding Series.

Anggaunitakiranantika, Hamidi, M. 2020. Emotional Entanglement and Community Empowerment of Transnational Migrants' Families: A Cross-Sectional Study in Malaysia and Indonesia. Glob Soc Welf 7 (4), 395-404. https://doi.org/10.1007/s40609-020-00191-3

Appadurai, A. 2006. Fear of Small Numbers. London: Duke University Press.

Bertrand, J. 2004. Nationalism and Ethnic Conflict in Indonesia. UK: Cambridge University Press.

Constable, N., 2010. Telling tales of migrant workers in Hong Kong: transformations of faith, life scripts, and activism. The Asia Pacific Journal of Anthropology, 11(3-4), pp. 311-329.

Ford, M and Parker, L. 2008. Women and Work in Indonesia. London: Routledge.

Hamidi, M. 2017. Indonesian Women and Their Unique Transnational Migration Experiences in Malaysia. Home and Away. Kuala Lumpur: University of Malaya Press.

Ionesco, D, and Christine A. 2009. Introduction, Gender and Labor Migration in Asia, Switzerland: International Organization for Migration.

Kiranantika, A., 2020. Arising in Migration: Forming a Power through Connectivity for Javanese Women. KnE Social Sciences, pp. 312-327. DOI: https://doi.org/10.18502/kss.v4i10.7419

Koning, J \& Nordic Institute of Asian Studies. 2000. Women and households in Indonesia: cultural notions and social practices. Surrey: Curzon Richmond

Mahler, S.J. and Pessar, P.R., 2001. Gendered geographies of power: Analyzing gender across transnational spaces. Identities, 7:4, 441-459, DOI: 10.1080/1070289X.2001.9962675

Miles, M.B and M. B. Huberman. 1994. Qualitative Data Analysis: An Expanded Sourcebook (2nd Edition). London: Sage Publication.

Neuman, Lawrence W. 2000. Social Research Methods: Qualitative and Quantitative Approaches, A Pearson Education Company. United States of America.

Rapoport, R., Bailyn, L., Fletcher, J.K and Pruitt, B.H. 2002. Beyond Work-Family Balance: Advancing Gender Equity and Workplace Performance. San Francisco: Jossey Bass.

Ridgeway, C. L., and Shelley J. C. 2004. Unpacking the Gender System: A Theoretical Perspective on Gender Beliefs and Social Relations. Gender \& Society, vol. 18, no. 4, Aug. 2004, pp. 510-531, doi: $10.1177 / 0891243204265269$.

Runnals, D. R. 2002. Gender Concept in Female Identity Development. Women in Indonesian Society: Access, Empowerment and Opportunity. Yogyakarta: Sunan Kalijaga Press.2002

Sheller, M. 2011. Mobility. Sociopedia.isa. USA. Doi: 10.1177/205684601163

Skeggs, B. 2004. Class, Self, Culture. London: Routledge.

Turner, V. 1974. The Ritual Process. London: Pelican Books.

Williams, C. P., \& Widodo, A. 2009. Circulation, Encounters and Transformation: Indonesian Female Migrants. Asian and Pacific Migration Journal, 18(1), 123-142. https://doi.org/10.1177/011719680901800106 